Marwah Bin Talib1, Abdullah A. Baredhwan², Khaled Alenazi', Ali Almagooshi2,

Abdulrehman M. Alqahtani', Sultan A. Alsobayeg2', Sarah Alhazmi', Waad Awad',

Ameera S. Alamri', Parameaswari P. Jaganathan'2, Manasik N. Abdu3, Latif Ahmed Khan²

${ }^{1}$ King Faisal Specialist Hospital, Kingdom of Saudi Arabia

${ }^{2}$ King Saud Medical City, Riyadh, Kingdom of Saudi Arabia

${ }^{3}$ College of Medicine, Al-Faisal University, Riyadh, Saudi Arabia

\title{
Clinical characteristics of COVID-19 patients at King Saud Medical City: a retrospective study
}

For citation: Mižnarodnij endokrinologičnij žurnal. 2021;17(1):3-10. doi: 10.22141/2224-0721.17.1.2021.226424

\begin{abstract}
Background. COVID-19, a new viral disease caused by Corona Virus (SARS-CoV-2) was reported first by Chinese. WHO declared it a pandemic in March 2020. We saw a huge number of this illness that caused a stress on health care systems and a high proportion of mortality. World Health Organization declared it as a pandemic in March 2020. We planned this study with the objective of knowing clinical presentation, hospital management and final outcome of COVID-19 in our population and compare it with other institution who studied the disease elsewhere. Materials and methods. A retrospective study on COVID-19 patients with severe to critical illness was conducted in King Saud Medical City Riyadh. Proper permission was issued by ethical committee of King Saud Medical City. Data was collected manually as well from electronic records. Data was analyzed using standard statistical methods. A total of 689 patients that were admitted to KSMC from $1^{\text {st }}$ March 2020 to $30^{\text {th }}$ of June 2020. Results. More than $50 \%$ of our patients were from Indian subcontinent (India, Pakistan and Bangladesh). Our mean age was 50 years. Females comprised $17.3 \%$ of our patients. Common presentation was breathlessness (79\%), cough (70\%) and fever (67\%). Mean oxygen saturation on presentation was $92 \%$. Around sixty one percent of our patients were critical and were treated in intensive care unit. Mortality was $35 \%$ and multi-organ failure $25 \%$. Although diabetes mellitus (37.3\%) and hypertension (29.5\%) were common comorbidities but it did not increase the mortality in our patients. Our mortality seems to be related to late reporting to hospital and severe disease itself. Conclusions. A retrospective study conducted at King Saud Medical city on 689 patients of severe and critical COVID-19. A high proportion were admitted to intensive care unit (60.8\%), $41 \%$ needed invasive ventilation and $29 \%$ required vasopressors and $14 \%$ needed hemodialysis. Mortality of $35 \%$ was recorded in our study. People of Indian subcontinent (Pakistani, Bangladeshi and Indians) formed more than $50 \%$ of patients.
\end{abstract}

Keywords: COVID-19; diabetes mellitus; hypertension; Kingdom of Saudi Arabia

\section{Introduction}

Since December 2019, cases of pneumonia due to new coronavirus were reported in Wuhan, China which spread rapidly in China to become an outbreak $[1,2]$. It was declared by World Health Organization (WHO) as a global emergency then as a pandemic on March 11, 2019 [3]. This virus has been identified as a new beta coronavirus. Later on, it received the name of severe acute respiratory syndrome coronavirus 2 (SARS-CoV-2) while the disease was named Coronavirus disease 19 (COVID-19). SARSCoV-2 was similar phylogenetically to Severe Acute Respiratory Corona Virus (SARS-CoV) by around $79 \%$ $[2,4,5]$.

Initial reports from China found that around $81 \%$ of the patients have a mild disease, while $14 \%$ have severe disease and $5 \%$ have a critical disease with higher mor-

For correspondence: Marwah Bin Talib, King Saud Medical City, 7752, al Imam Abdul Aziz Ibn Mohamad Ibn Saud, 3538, Riyadh, 127 46 3538, Saudi Arabia; e-mail: mbintalib@alfaisal.edu; contact phone: +966552149232

Full list of author information is available at the end of the article. 
tality among hospitalized and critically ill patients [6], however asymptomatic infection was representing around $30-40 \%$ in some reports $[7,8]$.

The disease can affect all people with some patients have a risk to develop severe disease and higher mortality than the others, these include patients with advanced age and patients who have comorbid illness [9].

The first case reported in Saudi Arabia was on March 2, 2020, the total number of confirmed cases in Kingdom of Saudi Arabia till November 29, 2020, reached 356.911 cases with total mortality of 5870 patients $[10,11]$.

\section{Materials and methods}

King Saud Medical City (KSMC) is one of the major tertiary care hospitals in Riyadh. This Ministry of Health Hospital has a capacity of 1200 beds and had some 400 intensive care unit (ICU) beds during the peak of the pandemic in May to August 2020. We conducted a retrospective study on patients admitted to KSMC starting from 1st March to $30^{\text {th }}$ June 2020. Very few patients were admitted in March. Most of the patients analyzed were admitted in April, May, and June 2020. Proper permission was secured from the Research center ethical committee of KSMC. We prepared an electronic excel sheet to collect the data. One of the researchers was given a job to keep all the online records of the data so extracted. A list of patients admitted during the period was acquired. Each file was physically examined by one of the authors. We extracted information like presenting symptoms, duration of symptoms, admission vital signs, oxygen saturation on admission, arterial blood gas, an electrocardiograph (ECG). This data was not available in electronic records of the patients. Other data that were also extracted manually were comorbidities, days spent in wards and ICU, and treatments given in ICU. The rest of the data like complete blood counts (CBC), acute phase reactants, inflammatory markers, biochemistry parameters, X-rays, computed tomography scans, and treatments given was extracted from electronic records. Each researcher extracted as much information as possible. SARS-CoV-2 PCR results were also extracted from a separate national-level data bank results were centrally reported and released. Two more researchers rechecked the data for its accuracy and searched for any missing data. All data was finally reviewed by the principal investigator, any patient with major missing data were removed from the data bank We analyzed the data for 694 patients. In the case of five patients, the data was grossly incomplete and they were removed from the observation. The remaining 689 patients were analyzed. The data were analyzed using SPSS (IBM SPSS Statistics for Windows, Version 24.0. Armonk, NY: IBM Corp). The categorical variables were presented in frequency and percentage for the deceased and discharged patients separately. The nonnormal variables INR, Ferritin, ESR, CRP, LDH, D-Dimer, BUN, Creatinine, ALT, AST, ASP, days of Ventilator support, days in ICU, days in the ward, stay in Hospital are presented as Median and Interquartile range (IQR) and tested using independent samples Mann-Whitney $\mathrm{U}$ test between the two groups - those who expired and discharged. The continuous variables BP, Pulse, Respiratory Rate, Oxygen $\left(\mathrm{O}_{2}\right)$ Saturation, Temperature, Blood Sugar, White Blood Cells, Lymphocyte, Platelets, Hemoglobin are presented as Mean, standard deviation (SD) and tested using student - t-test for independent samples. The non-parametric Chi-square test was used for the distribution of patients in the normal and abnormal values of all the characteristics measured on the outcome variable. The measure of association and the differences between the outcome variables were all statistically tested for two-tailed at 0.05 level of significance.

\section{Results}

Out of 689 patients, $118(17.1 \%)$ were females. Age ranged from 19 years to 100 years with a mean age of 50.511, and standard deviation (SD) of 13.86. Median age was 50.5 with an interquartile range $\left(25^{\text {th }}\right.$ to $\left.75^{\text {th }}\right)$ of 40 to 59 years. We had patients of 25 nationalities. Pakistanis were the highest numbers $(n=136,19.7 \%)$, followed by Bangladeshi $(n=129,18.7 \%)$, Indians $(n=92,13.4 \%)$, Saudis $(n=79,11.4 \%)$, Sudanese $(n=39,5.2 \%)$, Filipinos $(n=34,4.9 \%)$. All other nationalities formed the rest of our population, none exceeding 30 in numbers. Indians, Bangladeshis and Pakistanis to gather formed more than $50 \%$ of our population $(\mathrm{n}=357,51.8 \%)$, commonest presenting symptoms was breathlessness $(n=544,79 \%)$, followed by cough $(n=482,70.1 \%)$, fever $(n=463,67.2 \%)$, neurological symptoms $(n=65$, $9.4 \%$ ), and gastroenterological symptoms, vomiting and diarrhea $(n=50,7.3 \%)$. Duration of symptoms was less than 7 days in $92.6 \%(n=638)$ and more than 7 days in $7.3 \%(\mathrm{n}=50)$. Comorbidities, seen were diabetes mellitus $(\mathrm{DM})$ in $37.3 \%(\mathrm{n}=257)$, hypertension in $29.5 \%$ $(n=203)$, bronchial asthma in $7.3 \%(n=50)$, ischemic heart diseases in $41(6 \%)$, end stage renal disease (ESRD) in $24(3.5 \%)$.

$\mathrm{X}$-ray chest showed bilateral opacities on admission in 563 patients $(87.5 \%)$ and $16.7 \%$ of patients (115) had bilateral opacities that involved more than $50 \%$ of lung field on either side. ECG was normal in $58.8 \%$ of the patients. The commonest abnormality seen was sinus tachycardia $(40.5 \%)$. Antibiotics were given to $91.8 \%$ (633) patients. Most commonly Ceftriaxone and Azithromycin were used. Triple antiviral combination (Ribavirin Plus a combination of Ritonavir plus and Interferon alpha) was received by $33.5 \%$ of patients (232), Favipiravir was received by $18.8 \%$ (130) patients. Multivitamins like vitamin $\mathrm{C}$ and vitamin D plus Zinc were received by $74.9 \%$ of patients $(n=516)$. Steroids were not received by $164(23.9 \%)$ and the rest all received some form of steroids. Anticoagulants were received by most patients, $19 \%$ of patients $(n=131)$ received therapeutic doses of low molecular weight heparin, and 42 patients $(6.1 \%$ receive therapeutic unfractionated heparin infusions. Tocilizumab was given to 32 patients $(4.6 \%)$ ). 252 patients (36.6\%) were admitted directly to ICU from the Emergency Department. Remaining 432 patients (62.7\%) were admitted to isolation wards. Out of these 167 were subsequently shifted to ICU, because of deterioration, making a total of 419 patients $(60.8 \%)$ who required ICU 
Table 1. Depicting the distribution of age, clinical and laboratory parameters with numbers and percentages in discharged and deceased groups, $\boldsymbol{n}(\%)$

\begin{tabular}{|c|c|c|c|}
\hline Variables & $\begin{array}{c}\text { Discharged } \\
(n=448)\end{array}$ & $\begin{array}{c}\text { Deceased } \\
(n=241)\end{array}$ & $\begin{array}{c}\text { Total } \\
(100 \%)\end{array}$ \\
\hline Age (years) - 14-20 & $1(100)$ & 0 & 1 \\
\hline $21-30$ & $25(80.6)$ & $6(19.4)$ & 31 \\
\hline $31-40$ & $101(72.1)$ & 39 (27.9) & 140 \\
\hline $41-50$ & $118(69.8)$ & $51(30.2)$ & 169 \\
\hline $51-60$ & $131(63.9)$ & $74(36.1)$ & 205 \\
\hline $61-70$ & $43(52.4)$ & $39(47.6)$ & 82 \\
\hline$>70$ & $27(49.1)$ & $28(50.9)$ & 55 \\
\hline SBP $<90$ & $6(54.5)$ & $5(45.5)$ & 11 \\
\hline 90-140 (Normal) & $323(65.3)$ & $172(34.7)$ & 495 \\
\hline$>140$ & $119(65)$ & $64(35)$ & 183 \\
\hline $\mathrm{DBP}<60$ & $25(45.5)$ & $30(54.5)$ & 55 \\
\hline 60-90 (Normal) & $338(65.8)$ & $176(34.2)$ & 514 \\
\hline$>90$ & $85(70.8)$ & $35(29.2)$ & 120 \\
\hline$W B C<4$ & $11(64.7)$ & $6(35.3)$ & 17 \\
\hline 4-10 (Normal) & $227(66)$ & $117(34)$ & 344 \\
\hline$>10$ & $208(64)$ & $117(36)$ & 325 \\
\hline $\mathrm{Hb}<12$ & $80(61.5)$ & $50(38.5)$ & 130 \\
\hline 12-15 (Normal) & $302(67.3)$ & $147(32.7)$ & 449 \\
\hline$>15$ & $65(59.6)$ & $44(40.4)$ & 109 \\
\hline Hct $<36$ & $66(64.7)$ & $36(35.3)$ & 102 \\
\hline 35-46 (Normal) & $296(65.8)$ & $154(34.2)$ & 450 \\
\hline$>46$ & $84(62.7)$ & $50(37.3)$ & 134 \\
\hline Lymphocyte < 1 & $112(54.6)$ & $93(45.4)$ & 205 \\
\hline 1-3 (Normal) & 279 (69.9) & $120(30.1)$ & 399 \\
\hline$>3$ & $15(57.7)$ & $11(42.3)$ & 26 \\
\hline INR $<0.8$ & 0 & 0 & 0 \\
\hline $0.8-1.2$ (Normal) & $352(68)$ & $166(32)$ & 518 \\
\hline$>1.2$ & $91(55.2)$ & $74(44.8)$ & 165 \\
\hline $\mathrm{O}_{2}$ saturation $<95 \%$ & $365(62.4)$ & $220(37.6)$ & 585 \\
\hline$>95 \%$ (Normal) & $83(79.8)$ & $21(20.2)$ & 104 \\
\hline Glucose $<4.1$ & $9(90)$ & $1(10)$ & 10 \\
\hline 4.1-5.9 (Normal) & $42(75)$ & $14(25)$ & 56 \\
\hline$>5.9$ & $396(64.1)$ & $222(35.9)$ & 618 \\
\hline Urea $<2.8$ & $10(100)$ & 0 & 10 \\
\hline 2.8-7.2 (Normal) & $157(86.3)$ & $25(13.7)$ & 182 \\
\hline$>7.2$ & $269(56)$ & $211(44)$ & 480 \\
\hline Creatinine $<45$ & $8(100)$ & 0 & 8 \\
\hline 45-84 (Normal) & $110(85.9)$ & $18(14.1)$ & 128 \\
\hline$>84$ & $321(59.6)$ & $218(40.4)$ & 539 \\
\hline AST < 35 (Normal) & $73(82)$ & $16(18)$ & 89 \\
\hline$>35$ & $363(62.7)$ & $216(37.3)$ & 579 \\
\hline ALT < 35 (Normal) & $84(72.4)$ & $32(27.6)$ & 116 \\
\hline$>35$ & $353(63.9)$ & $199(36.1)$ & 552 \\
\hline LDH $<208$ & $14(82.4)$ & $3(17.6)$ & 17 \\
\hline 208-378 (Normal) & $44(93.6)$ & $3(6.4)$ & 47 \\
\hline$>378$ & $366(61.5)$ & $229(38.5)$ & 595 \\
\hline Ferritin $<22$ & $23(53.5)$ & $20(46.5)$ & 43 \\
\hline 22-322 (Normal) & $49(69.0)$ & $22(31)$ & 71 \\
\hline$>322$ & $272(62)$ & $167(38)$ & 439 \\
\hline
\end{tabular}


admission. Out of these patients, 288 patients $(41.8 \%$ required invasive ventilation, 30 patients $(4.4 \%)$ required noninvasive ventilation, and the rest all received oxygen, either by nasal cannula or by a non-rebreathing mask. 200 patients $(29 \%)$ needed vasopressors, $97(14.1 \%)$ needed dialysis, $82(11.9 \%)$ received plasmapheresis, $6(0.9 \%)$ were given convalescent plasma, 5 patients $(0.7 \%)$ were put on Extra Corporeal Membrane Oxygenator (ECMO) and $10(1.5 \%)$ developed hospital-acquired pneumonia. Out of 689 patients, 257 had DM with a mortality of 100 $(38.9 \%)$, and the remaining nondiabetics, mortality was $32.6 \%$. This difference was not significant $(p=0.93)$. Similarly, 203 patients were hypertensive with a mortality of $81(39.9 \%)$ compared to a mortality of 160 out of 486 among non-hypertensive (32.92\%). The difference was not significant (0.912). Tables 1 and Table 2 below depicts the further distribution of a variable.

Abbreviations used in Tables: SBP - Systolic Blood Pressure, mm Hg; DBP - Diastolic blood pressure, mm $\mathrm{Hg}$; WBC - white blood cell Count. $10 \times 9 / 1$; Hb - Hemoglobin, gm/dl; Hct - Hematocrit, \%; INR - International Normalized Ratio; AST - Aspartate aminotransferase, Units per liter; ALT - Alanine aminotransferase, Units per liter; ALP - Alkaline Phosphatase, Units per liter; LDH Lactate Dehydrogenase, Units per liter; CRP - C Reactive protein; ESR - Erythrocyte Sedimentation Rate, $\mathrm{mm} / 1^{\text {st }}$

Table 2. Depicting differences of different clinical and laboratory variables with mean and standard deviation (SD) and median with interquartile range (IQR) where relevant, Mean \pm SD

\begin{tabular}{|c|c|c|c|c|}
\hline Variables & Overall & $\begin{array}{c}\text { Discharged } \\
(n=448)\end{array}$ & $\begin{array}{c}\text { Deceased } \\
(n=241)\end{array}$ & $P$-value \\
\hline Age & $50.5 \pm 13.8$ & $48.9 \pm 13.2$ & $53.3 \pm 14.4$ & $0.000^{*}$ \\
\hline SBP & $130.1 \pm 22.5$ & $130.6 \pm 20.8$ & $129.1 \pm 25.5$ & 0.388 \\
\hline DBP & $78.1 \pm 15.3$ & $79.2 \pm 14.8$ & $76.0 \pm 16.1$ & $0.010^{*}$ \\
\hline Pulse & $104.7 \pm 19.8$ & $102.9 \pm 19.1$ & $108.2 \pm 20.5$ & $0.001^{*}$ \\
\hline Respiratory Rate (RR) & $27.2 \pm 8.3$ & $26.6 \pm 7.5$ & $28.4 \pm 9.6$ & $0.007^{*}$ \\
\hline Oxygen $\left(\mathrm{O}_{2}\right)$ Saturation & $84.1 \pm 13.0$ & $86.5 \pm 11.7$ & $79.7 \pm 14.1$ & $0.000^{*}$ \\
\hline Temperature & $37.4 \pm 2.0$ & $37.3 \pm 2.4$ & $37.6 \pm 0.9$ & 0.093 \\
\hline Blood Sugar & $12.3 \pm 14.8$ & $11.60 \pm 0.76$ & $13.60 \pm 0.77$ & 0.093 \\
\hline WBC & $10.8 \pm 4.9$ & $10.5 \pm 4.7$ & $11.3 \pm 5.4$ & 0.052 \\
\hline Lymphocyte & $1.4 \pm 0.9$ & $1.40 \pm 0.74$ & $1.40 \pm 0.08$ & 0.986 \\
\hline Platelets & $265.8 \pm 102.2$ & $275.1 \pm 99.7$ & $248.6 \pm 104.6$ & $0.001^{*}$ \\
\hline Haemoglobin (Hb \%) & $13.3 \pm 2.1$ & $13.3 \pm 2.0$ & $13.3 \pm 2.2$ & 0.996 \\
\hline INR, Median (IQR) & $1.1(1.0-1.2)$ & $1.1(1.02-1.19)$ & $1.13(1.02-1.25)$ & 0.06 \\
\hline Hct & $41.30 \pm 6.47$ & $41.2 \pm 6.2$ & $41.4 \pm 6.8$ & 0.723 \\
\hline Ferritin, Median (IQR) & $955(412-1547)$ & $832(385-1463)$ & $1203(491-1848)$ & $0.001^{*}$ \\
\hline ESR, Median (IQR) & $76(14.5-110.2)$ & 75.5 (12.2-107) & $77(20.5-115)$ & 0.529 \\
\hline CRP, Median (IQR) & 115 (33.2-194) & $82.6(21.2-163)$ & 177.5 (82.1-229) & $0.000^{*}$ \\
\hline LDH, Median (IQR) & $1121(656-1736)$ & $863(521-1264.9)$ & $1801(1154-2941)$ & $0.000^{*}$ \\
\hline D-Dimer, Median (IQR) & $3.8(1.3-14.9)$ & $2.1(1.0-7.5)$ & $10.5(3.58-21.6)$ & $0.000^{*}$ \\
\hline $\mathrm{K}^{+}$(Initial), Median (IQR) & $4.0(3.6-4.5)$ & $4(3.6-4.4)$ & $4.2(3.7-4.7)$ & $0.002^{*}$ \\
\hline $\mathrm{K}^{+}$(Highest), Median (IQR) & $5.1(4.6-5.7)$ & $5.1(4.5-5.4)$ & $5.4(4.9-6)$ & $0.000^{*}$ \\
\hline $\mathrm{K}^{+}$(Lowest), Median (IQR) & $3.6(3.3-3.9)$ & $3.6(3.3-4.0)$ & $3.5(3.2-3.9)$ & $0.005^{*}$ \\
\hline $\mathrm{Na}^{+}$(Initial) & $138.4 \pm 7.2$ & $138.4 \pm 7.7$ & $138.5 \pm 6.4$ & 0.85 \\
\hline $\mathrm{Na}^{+}$(Highest) & $147.3 \pm 50.5$ & $145.3 \pm 61.5$ & $151 \pm 14.7$ & 0.164 \\
\hline $\mathrm{Na}^{+}$(Lowest) & $134 \pm 5$ & $134.1 \pm 4.8$ & $134.0 \pm 5.2$ & 0.804 \\
\hline BUN, Median (IQR) & $10.2(6.8-22.1)$ & $8.2(6-11)$ & $24.6(13-41)$ & $0.000^{*}$ \\
\hline Cr, Median (IQR) & $115.5(88.0-224.2)$ & $101(82-130)$ & $254(118-454)$ & $0.000^{*}$ \\
\hline ALT, Median (IQR) & $88(45.1-164.5)$ & $80.4(41.2-137.2)$ & $110.4(56-252)$ & $0.000^{*}$ \\
\hline AST, Median (IQR) & $91(49.7-181.3)$ & $74.9(43-131)$ & $163.9(75.7-395.7)$ & $0.000^{*}$ \\
\hline ALP, Median (IQR) & $121.6(84.7-182.3)$ & $106(78-155)$ & $152(107-247)$ & $0.000^{*}$ \\
\hline Days of Hospitalization, Median (IQR) & $11(7-16)$ & $10(6-15)$ & $12(7-18)$ & $0.008^{*}$ \\
\hline Days in ICU, Median (IQR) & $4(2-7)$ & $6(4-9)$ & $3(1.8-5.0)$ & $0.000^{*}$ \\
\hline Days on Ventilatory Support, Median (IQR) & $7(3-12)$ & $6.5(3-11)$ & $7.5(3-12)$ & $0.016^{*}$ \\
\hline Days in the Ward, Median (IQR) & $4(2-8)$ & $7(4.0-9.7)$ & $3(1.8-5.0)$ & $0.000^{*}$ \\
\hline
\end{tabular}

Notes: * - statistically significant at $5 \%$ level; IQR - Interquartile Range. 
hour; BUN - Blood Urea Nitrogen, mmol/1; Cr. - Creatinine, mcmol/l; $\mathrm{K}^{+}$- Potasium, $\mathrm{Na}^{+}$- Sodium, mmol/l.

\section{Discussion}

King Saud Medical City (KSMC) is a tertiary care hospital of the Ministry of Health, Kingdom of Saudi Arabia. People from all nationalities get medical care in this hospital. It is a large hospital with around 1200 bed capacity. During the pandemic, asymptomatic and mild cases were not admitted to our hospital. Such patients were either going to special quarantine centers or transferred to another hospital, so most of our cases were either severe or critical cases as per the classification of the local Ministry of Health guidelines [12].

The mean age of our patients was 50 years. The median age was 50.5 years with an interquartile ranged from 40 to 59 years, comprising $50 \%$ of our patients, $17.0 \%$ were females, more than $50 \%$ of our patients were from Bangladesh, India, and Pakistan (Indian Subcontinent), and the rest, less than $50 \%$ were from the Middle East and some North African countries. This proportion reflects the proportion of expatriates in the Kingdom. Further, all expatriates had free access to healthcare facilities during the pandemic. Our patients had more severe disease and had higher death rates. This severe disease could be attributed to social reasons like living in smaller rooms with less ventilation and more people staying per room. Further because of overcrowding they were taking fewer protective measures in the initial period of the pandemic. Whether genetic factors are contributing to this outcome needs to be studied separately.

Because of severe disease on admission, $60.8 \%$ of our patients were treated in ICU, $36.6 \%$ of them were directly admitted to ICU as they presented in critical condition, the remaining patients were transferred from the wards. During the initial days of the pandemic, invasive ventilation was the carried-out routine for the respiratory failure of COVID-19, so $41.0 \%$ required invasive ventilation and another $4.4 \%$ required noninvasive ventilation. A high proportion of $29 \%$ was on vasopressors, and $14.1 \%$ received hemodialysis, this might explain our high mortality rate than locally reported by other studies. The mortality rate of up to $50 \%$ and above was reported in patients with severe COVID-19 from the USA and China [13-15], a mortality of $50 \%$ among patients admitted to ICU was also reported locally by Barry et al. [16].

Although $92.6 \%$ of our patients reported having a duration of symptoms less than 7 days, $87.5 \%$ had bilateral opacities on initial X-ray chest, $16.7 \%$ of them had severe $\mathrm{X}$-ray findings, that involved more than $50 \%$ of the lung area bilaterally. This supports the concept that patients had severe viral pneumonia. However inflammatory markers were also high, so the contribution of cytokine storm was adding fuel to the fire. Median oxygen saturation on admission was $87 \%$ and $75 \%$ of admitted patients had oxygen saturation less than $93 \%$ on admission. All these features suggest that our patients were extremely sick and critical on admission.

Out of all comorbidities, $37.3 \%$ had DM, $29.5 \%$ had hypertension, $7-3 \%$ bronchial asthma, and $6 \%$ had heart disease. Only $1.6 \%$ was found to be obese based on history documented in the charts because the body mass index was not calculated routinely, however it was not a major prognostic factor for mortality or severe disease in our population although it was documented to be so in other studies including one systematic review [17]. Neither hypertension nor was DM or obesity a risk factor for higher mortality in our patients. All our ESRD patients were admitted routinely if they tested positive even without symptoms. This was because they needed regular dialysis in the hospital and they were therefore not sent to separate isolation centers meant for asymptomatic patients. ESRD patients comprised $3.5 \%$ of our patients. To our utter surprise, most of such patients were asymptomatic or just had mild symptoms, other studies showed higher mortality among patients with ESRD but having fewer respiratory symptoms [18, 19].

Age was significantly higher in deceased patients and so were the days of hospitalization, this was also reported from studies in the USA, China, and Italy [6, 20, 21]. Pulse rate on admission was higher (110 versus 103) and oxygen saturation was lower ( $82 \%$ versus $88 \%)$. Out of acute inflammatory markers, we found serum ferritin (1144.9/853), CRP (82/75), LDH (1840/1024), and D dimer (11.8/2.2) higher in the deceased group than those who survived. Similarly, serum creatinine (254/101) ALT (110/80) AST (163/74.9) and ALP (247/106) were all significantly higher in deceased patients. A couple of studies published from Saudi Arabia and other countries had an almost similar observation [16, 22, 23].

Most of our patients received supportive treatment, oxygen when necessary, antibiotics especially azithromycin, and one of the presumptive treatments (Hydroxychloroquine, triple antiviral therapy, or Favipiravir) was given depending on regular updates from the ministry of health guidelines. Steroids were received by almost all patients who needed ICU management. However, we used Methylprednisolone initially in different doses as it was not standardized. But subsequently, when new data became available, dexamethasone was used. A few patients also receive Tocilizumab as a part of an investigational drug. Dexamethasone was conclusively proved to reduce mortality in ventilated patients and those who need oxygen therapy and we have used Dexamethasone in some of our patients.

\section{Conclusions}

Our patients comprised of a heterogeneous group of patients representing 25 nationalities with Pakistanis, Bangladeshi, and Indians making more than $50 \%$ of the total. The majority of these patients $>90 \%$ were severe and critical COVID-19. More than $60 \%$ were admitted to ICU. Multiple organ failure was seen in more than $25 \%$ of the patients. Mortality was $35 \%$ and low initial oxygen saturation and high serum ferritin, LDH, CRP, and high D-dimer were associated with high mortality. Diabetes mellitus, hypertension was present in a high percentage of patients but mortality was not affected by these comorbidities. Obesity was not present in many patients and was not a contributing factor. Initial severe disease possibly related to high viral load or late presen- 
tation to the hospital was thought to be the main reason for high mortality. Steroids were received by all except mild to moderate cases.

\section{Acknowledgement}

We sincerely acknowledge the help of Norhaya U. Abutazil, Secretary in Directors Office for extracting patient numerical identity and tallying it with physical identity and for her help in entering the data and counter checking some data and laboratory parameters.

Author Contribution. Latif Khan is the primary investigator. He conceived the idea and designed the study. He also checked the final data and wrote the manuscript for final publication. Marwa bin Talib was the research coordinator, maintaining the online data sheets and updated the data from time to time. She was also involved in writing the research proposal and following the proposal in research center and final uploading of manuscript. She was also involved in extracting the data from files manually. Abdullah Baredwan was involved in review of literature and refining the final manuscript. He was also involved in reviewing of data and interpretation of some of the data. Khalid Alenazi was involved in mobilization of records, organizing the administrative support for proper collection and extraction of data. Ali Almagooshi and Abdulrehman Alqahtani were involved in extracting data physically and later counter checking the entire data. Sultan Alsobayeg, Waad Awad, Ameera Alamri and Sarah Alhazmi were involved in data collection from the files. Manasik Abdu did the radiology data extraction. Parameaswari Jaganathan has done the statistical work of the research and formulated the Tables used in the manuscript.

Funding. No funding was sought or received from any source for this research. Money was spent from the personal pocket wherever necessary.

Availability of Data. Data is available in electronic form. Both original Excel sheets and Statistical outputs are available, if needed.

Ethics and approval. Proper approval was received from Ethical committee of Research center of King Saud Medical City, Riyadh, Saudi Arabia. It can be produced on demand.

Consent of Participants. Ours was a retrospective study, so no consent was required or sort from patients.

Conflict of Interest. None of the authors has declared any conflict of interest.

Guarantor. Khalid Alenazi is the guarantor of this research project and is the administrative head of the study.

Consent for Publication. All authors have given the consent for publication of this work.

\section{References}

1. World Health Organization. Novel Coronavirus (2019nCoV). WHO. 2020. Available from: https://www.who.int/ emergencies/diseases/novel-coronavirus-2019.

2. Tan W, Zhao X, Ma X, et al. Notes from the Field: A Novel Coronavirus Genome Identified in a Cluster of Pneumonia Cases - Wuhan, China 2019-2020. China CDC Weekly. 2020;2(4):6162. doi:10.46234/ccdcw2020.017.
3. Sohrabi C, Alsafi Z, O'Neill N, et al. World Health Organization declares global emergency: A review of the 2019 novel coronavirus (COVID-19). Int J Surg. 2020 Apr;76:71-76. doi:10.1016/j.ijsu.2020.02.034.

4. Lu R, Zhao X, Li J, et al. Genomic characterisation and epidemiology of 2019 novel coronavirus: implications for virus origins and receptor binding. Lancet. 2020 Feb 22;395(10224):565574. doi:10.1016/S0140-6736(20)30251-8.

5. Pal M, Berhanu G, Desalegn C, Kandi V. Severe Acute Respiratory Syndrome Coronavirus-2 (SARS-CoV-2): An Update. Cureus. 2020 Mar 26;12(3):e7423. doi:10.7759/cureus. 7423.

6. Wu Z, McGoogan JM. Characteristics of and Important Lessons From the Coronavirus Disease 2019 (COVID-19) Outbreak in China: Summary of a Report of 72314 Cases From the Chinese Center for Disease Control and Prevention. JAMA. 2020 Apr 7;323(13):1239-1242. doi:10.1001/jama.2020.2648.

7. Oran DP, Topol EJ. Prevalence of Asymptomatic SARSCoV-2 Infection : A Narrative Review. Ann Intern Med. 2020 Sep 1;173(5):362-367. doi:10.7326/M20-3012.

8. Lavezzo E, Franchin E, Ciavarella C, et al; Imperial College COVID-19 Response Team. Suppression of a SARSCoV-2 outbreak in the Italian municipality of Vo'. Nature. 2020 Aug;584(7821):425-429. doi:10.1038/s41586-020-2488-1.

9. Meyerowitz-Katz G, Merone L. A systematic review and meta-analysis of published research data on COVID-19 infection fatality rates. Int $J$ Infect Dis. 2020 Dec;101:138-148. doi:10.1016/j.ijid.2020.09.1464.

10. Alsofayan YM, Althunayyan SM, Khan AA, Hakawi AM, Assiri AM. Clinical characteristics of COVID-19 in Saudi Arabia: A national retrospective study. J Infect Public Health. 2020 Jul;13(7):920-925. doi:10.1016/j.jiph.2020.05.026.

11. COVID 19 Dashboard: Saudi Arabia. Available from: https://covid19.moh.gov.sa. Accessed: 29.11.2020.

12. Saudi MoH Protocol for Patients Suspected of/Confirmed with COVID-19 Supportive care and antiviral treatment of suspected or confirmed COVID-19 infection. Available from: https://covid19. cdc.gov.sal. Accessed: 09.12.2020.

13. Yang $X, Y u Y, X u J$, et al. Clinical course and outcomes of critically ill patients with SARS-CoV-2 pneumonia in Wuhan, China: a single-centered, retrospective, observational study. Lancet Respir Med. 2020 May;8(5):475-481. doi:10.1016/S22132600(20)30079-5.

14. Bhatraju PK, Ghassemieh BJ, Nichols M, et al. Covid-19 in Critically Ill Patients in the Seattle Region - Case Series. N Engl J Med. 2020 May 21;382(21):2012-2022. doi:10.1056/ NEJMoa2004500.

15. Wu C, Chen X, Cai Y, et al. Risk Factors Associated With Acute Respiratory Distress Syndrome and Death in Patients With Coronavirus Disease 2019 Pneumonia in Wuhan, China. JAMA Intern Med. 2020 Jul 1;180(7):934-943. doi:10.1001/ jamainternmed.2020.0994.

16. Barry M, AlMohaya A, AlHijji A, et al. Clinical Characteristics and Outcome of Hospitalized COVID-19 Patients in a MERS-CoV Endemic Area. J Epidemiol Glob Health. 2020 Sep;10(3):214-221. doi:10.2991/jegh.k.200806.002.

17. Tamara A, Tahapary DL. Obesity as a predictor for a poor prognosis of COVID-19: A systematic review. Diabetes Metab Syndr. 2020 Jul-Aug;14(4):655-659. doi:10.1016/j. dsx.2020.05.020.

18. Wang D, Hu B, Hu C, et al. Clinical Characteristics of 
138 Hospitalized Patients With 2019 Novel Coronavirus-Infected Pneumonia in Wuhan, China. JAMA. 2020 Mar 17;323(11):10611069. doi:10.1001/jama.2020.1585.

19. Flythe JE, Assimon MM, Tugman MJ, et al; STOPCOVID Investigators. Characteristics and Outcomes of Individuals With Pre-existing Kidney Disease and COVID-19 Admitted to Intensive Care Units in the United States. Am J Kidney Dis. 2021 Feb;77(2):190-203.e1. doi:10.1053/j.ajkd.2020.09.003.

20. Richardson S, Hirsch JS, Narasimhan $M$, et al. Presenting Characteristics, Comorbidities, and Outcomes Among 5700 Patients Hospitalized With COVID-19 in the New York City Area. JAMA. 2020 May 26;323(20):2052-2059. doi:10.1001/ jama.2020.6775.

21. Onder G, Rezza G, Brusaferro S. Case-Fatality Rate and Characteristics of Patients Dying in Relation to COVID-19 in Italy. JAMA. 2020 May 12;323(18):1775-1776. doi:10.1001/ jama.2020.4683.

22. Shabrawishi M, Al-Gethamy MM, Naser AY, et al. Clinical, radiological and therapeutic characteristics of patients with COVID-19 in Saudi Arabia. PLoS One. 2020 Aug 6;15(8):e0237130. doi:10.1371/journal.pone.0237130.

23. Guan W, Ni Z, Hu Y, et al. Clinical Characteristics of Coronavirus Disease 2019 in China. NEngl J Med. 2020;382:17081720. doi:10.1056/nejmoa2002032.

Received 11.01.2021

Revised 01.02.2021 Accepted 05.02.2021

\section{Information about authors}

Marwah Bin Talib, Department of Gynecology and Obstetrics, King Faisal Specialist Hospital, Kingdom of Saudi Arabia, Previously Intern, Department of Internal Medicine, King Saud Medical City; e-mail: mbintalib@alfaisal.edu

Abdullah A. Baredhwan, Consultant Infectious Diseases, King Saud Medical City, Kingdom of Saudi Arabia; e-mail: dr.baradwan@gmail.com

Khaled Alenazi, Consultant Internal Medicine, and Director of General Hospital, King Saud Medical City. Kingdom of Saudi Arabia; e-mail: Khalenezi@ksmc.med.sa

Ali Almagooshi, Internal Medicine, King Saud Medical City, Riyadh, KSA; e-mail: A.s.almagooshi@gmail.com

Abdulrehman M. Alqahtani, Internal Medicine, King Saud Medical City, Riyadh, KSA; e-mail: Abdalrahman111@hotmail.com

Sultan A. Alsobayeg, Internal Medicine, King Saud Medical City, Riyadh, KSA; e-mail: salsobayeg@gmail.com

Sarah Alhazmi, Internal Medicine, King Saud Medical city, Riyadh; e-mail:S.alhazmi@ksmc.med.sa

Waad Awad, Internal Medicine. King Saud Medical City, Riyadh; e-mail:Waad9311@hotmail.com

Ameera S. Alamri, Internal Medicine, King Saud Medical City, Riyadh; e-mail: Ameera.s.alamri4@gmail.com

Parameaswari P. Jaganathan, Statistician, Research center, King Saud Medical City, Saudi Arabia; e-mail: param@ksmc.med.sa

Manasik N. Abdu, College of Medicine, Al-Faisal University, Riyadh, Saudi Arabia; e-mail: manasik.abdu2020@gmail.com

Latif Ahmed Khan, Consultant Internal Medicine, King Saud Medical City (KSMC) Riyadh, Kingdom of Saudi Arabia (KSA), Primary Investigator; e-mail: I.khan@ksmc.med.sa

Marwah Bin Talib', Abdullah A. Baredhwan², Khaled Alenazi2, Ali Almagooshi², Abdulrehman M. Alqahtani²,

Sultan A. Alsobayeg2, Sarah Alhazmi2, Waad Awad², Ameera S. Alamri', Parameaswari P. Jaganathan²,

Manasik N. Abdu', Latif Ahmed Khan ${ }^{2}$

${ }^{1}$ King Faisal Specialist Hospital, Kingdom of Saudi Arabia

${ }^{2}$ King Saud Medical City, Riyadh, Kingdom of Saudi Arabia

${ }^{3}$ College of Medicine, Al-Faisal University, Riyadh, Saudi Arabia

\section{КАінічна характеристика пацієнтів з COVID-19: ретроспективне АОсліАження у Сауаівській Аравії}

Резюме. Актуальність. У Китаї вперше повідомили про вірусне захворювання COVID-19, спричинене коронавірусом (SARS-CoV-2). Всесвітня організація охорони здоров'я оголосила пандемію COVID-19 в березні 2020 року. Спостерігається значна кількість випадків цієї хвороби, яка стала тягарем для систем охорони здоров'я і призвела до високої летальності. Ціль. Дослідження сплановане з метою встановити особливості клінічної картини захворювання, ведення хворих і кінцеві результати лікування COVID-19 у популяції Королівства Саудівська Аравія та порівняти показники 3 іншими установами. Матеріали та методи. Ретроспективне дослідження пацієнтів із COVID-19 з тяжким перебігом і критичними станами було проведене в медичному центрі Ер-Ріяду. Дозвіл на його проведення виданий комітетом 3 етики медичного центру. Клінічні дані зібрані з електронних записів пацієнтів. Показники 689 пацієнтів, які зверталися за допомогою з 1 березня 2020 року по 30 червня 2020 року, аналізували за допомогою стандартних статистичних методів. Результати. Понад 50 \% пацієнтів (середній вік 50 років) були з Індійського субконтиненту (Індія, Пакистан і Бангладеш). Жінки становили 17,3 \% обстежених. По- ширеними явишами у хворих були задишка (79\%), кашель (70\%) і лихоманка (67\%). Середня насиченість крові киснем у них становила $92 \%$. Приблизно $61 \%$ пацієнтів перебували в критичному стані та лікувались у відділенні інтенсивної терапії. Смертність становила $35 \%$, а поліорганна недостатність $-25 \%$. Цукровий діабет належав до найчастіших супутніх станів (37,3\%), як і артеріальна гіпертензія $(29,5 \%)$. При цьому їх наявність не призводила до збільшення летальності цих пацієнтів. Показник летальності, очевидно, пов'язаний із несвоєчасним зверненням до медичних закладів та тяжкістю самої хвороби. Висновки. Наведені результати ретроспективного дослідження за участю 689 пацієнтів із тяжким перебігом COVID-19 свідчать про високу частку госпіталізацій у відділення інтенсивної терапії - 60,8 \%. 3 цього числа $41 \%$ хворих потребували інвазивної вентиляції легень, $29 \%$ - використання препаратів вазопресивної дії та $14 \%$ - проведення гемодіалізу. Смертність становила $35 \%$. Понад 50 \% хворих становили вихідці з Індійського субконтиненту.

Ключові слова: COVID-19; цукровий діабет; артеріальна гіпертензія; Королівство Саудівська Аравія 
Marwah Bin Talib1', Abdullah A. Baredhwan², Khaled Alenazi², Ali Almagooshi², Abdulrehman M. Alqahtani², Sultan A. Alsobayeg2, Sarah Alhazmi2, Waad Awad', Ameera S. Alamri', Parameaswari P. Jaganathan', Manasik N. Abdu', Latif Ahmed Khan²

${ }^{1}$ King Faisal Specialist Hospital, Kingdom of Saudi Arabia

2 King Saud Medical City, Riyadh, Kingdom of Saudi Arabia

${ }^{3}$ College of Medicine, Al-Faisal University, Riyadh, Saudi Arabia

\section{КАиническая характеристика пациентов с COVID-19: ретроспективное исслеАование в СауАовской Аравии}

Резюме. Актуальность. В Китае впервые сообщили о вирусном заболевании COVID-19, вызванном коронавирусом (SARS-CoV-2). Всемирная организация здравоохранения объявила пандемию COVID-19 в марте 2020 года. Наблюдается значительное количество случаев этой болезни, которая стала бременем для систем здравоохранения и привела к высокой летальности. Цель. Исследование спланировано с целью установить особенности клинической картины заболевания, ведения больных и конечные результаты лечения COVID-19 в популяции Королевства Саудовская Аравия и сравнить показатели с другими учреждениями. Материалы и методы. Ретроспективное исследование пациентов с COVID-19 с тяжелым течением и критическими состояниями было проведено в медицинском центре Эр-Рияда. Разрешение на его проведение выдано комитетом по этике медицинского центра. Клинические данные собраны из электронных записей пациентов. Показатели 689 пациентов, обращавшихся за помощью с 1 марта 2020 по 30 июня 2020 года, анализировали с помощью стандартных статистических методов. Результаты. Более 50 \% пациентов (средний возраст 50 лет) были с Индийского субконтинента (Индия, Пакистан и Бангладеш). Женщины составляли 17,3\% обследованных. Рас- пространенными явлениями у больных были одышка (79\%), кашель $(70 \%)$ и лихорадка $(67 \%)$. Средняя насышенность крови кислородом у них составляла $92 \%$. Примерно $61 \%$ пациентов находились в критическом состоянии и лечились в отделении интенсивной терапии. Смертность составляла $35 \%$, а полиорганная недостаточность $-25 \%$. Сахарный диабет принадлежал к наиболее частым сопутствующим состояниям (37,3\%), как и артериальная гипертензия (29,5\%). При этом их наличие не приводило к увеличению летальности этих пациентов. Показатель летальности, очевидно, связан с несвоевременным обращением в медицинские учреждения и тяжестью самой болезни. Выводы. Приведенные результаты ретроспективного исследования с участием 689 пациентов с тяжелым течением COVID-19 свидетельствуют о высокой доле госпитализаций в отделение интенсивной терапии $60,8 \%$. Из этого числа $41 \%$ больных нуждались в инвазивной вентиляции легких, $29 \%$ - в использовании препаратов вазопрессивного действия и $14 \%$ - в проведении гемодиализа. Смертность составляла $35 \%$. Более $50 \%$ больных составляли выходцы с Индийского субконтинента.

Ключевые слова: COVID-19; сахарный диабет; артериальная гипертензия; Королевство Саудовская Аравия 